\title{
Insecta and Collembola as bioindicators of ecological restoration in the Ombrophilous Dense Forest in Southern Brazil
}

\author{
Taise Cristina Plattau Arenhardt ${ }^{1}$ \\ Marcelo Diniz Vitorino ${ }^{2}$ \\ Sebastião Venâncio Martins ${ }^{1}$ \\ ${ }^{1}$ Universidade Federal de Viçosa, Departamento de Engenharia Florestal, Viçosa, MG, Brasil. \\ ${ }^{2}$ Universidade Regional de Blumenau, Departamento de Engenharia Florestal, Blumenau, SC, Brasil.
}

\begin{abstract}
The objective of this study was to evaluate the capacity as bioindicators of litter arthropodofauna in pasture restoration in the Atlantic Forest Biome. Areas of native forest under natural regeneration, and pastures treated with different ecological restoration techniques were evaluated, with pitfall traps. The sampling period was from April/2017 to October/2018, bimonthly. Families Ptiliidae, Staphylinidae, and Leiodidae, species Pheidole cf. sarcina (Formicidae) and Mastigoceras sp. 1 and Szeptyckitheca sp. 1 (Collembola) were indicators of well-conserved areas, whereas families Cicadellidae and Delphacidae, Formicidae species Wasmannia auropunctata (Roger, 1863) and Camponotus melanoticus Emery, 1894 were indicators of degraded areas. From the springtail community, species richness is a metric that can be used as a bioindicator. It was observed that all taxonomic identification levels allowed for the differentiation of the environmental conditions of the sampling areas, with less specific identification levels, such as family, possibly indicating changes in areas under the restoration process.
\end{abstract}

Keywords: Formicidae, monitoring, pitfall, Ptiliidae, taxonomy sufficiency.

\section{INTRODUCTION AND OBJECTIVES}

Insects constitute the most diverse faunal group (Lewinsohn \& Prado, 2005) and are involved in almost all ecological processes that occur in ecosystems (Lavelle et al., 2006). They are also notable for being one of the main groups providing ecosystem services, directly or indirectly benefiting humans through regulation, provision, support, and cultural services (Schowalter et al., 2018; Dangles \& Casas, 2019). Within this group, the ants (Hymenoptera: Formicidae) are an exceptional group because of their abundance, diversity, and functional importance, and are known as ecosystem engineers (Jones et al., 1994). Another notable group for its representativeness is the springtails (Hexapoda: Collembola) (Cassagne et al., 2003), which are small arthropods that act on soil formation, litter fragmentation, and fauna excrement (Rusek, 1998).

The Atlantic Rain Forest is recognized as one of the most endangered forests in the world because of anthropogenic use (Myers et al., 2000) and is exposed to different sources of degradation (Joly et al., 2014). In the State of Santa Catarina, the Ombrophilous Dense Forest phytophysiognomy has been reduced to $40.10 \%$ of its original cover and mostly consists of fragments of up to 50ha (Vibrans et al., 2013). Consequently, there are negative changes in the community of insect fauna (Bourg et al., 2016; Salomão et al., 2018), ant fauna (Silva et al., 2007), and springtail fauna (Rusek, 1998; Zeppelini et al., 2009).

Restoration consists of reverting a degraded ecosystem to an undegraded condition or as close as possible to its original condition (Brasil, 2000), considering aspects of biodiversity and ecological processes (SER, 2004). Restoration monitoring aims to provide information on the progress of the restoration process in the area (SER, 2004). One way to monitor the progress is by using indicators, which may reflect environmental conditions (Brancalion et al., 2012). Plant community parameters are often used as indicators of restoration (Suganuma \& Durigan, 2015). However, forest ecosystems are highly complex, and for efficient observation of restoration strategies, multiple functional, structural, and compositional variables (Gatica-Saavedra et al., 2017) as well as ecological processes that reflect other attributes of 
the ecosystems (Herrick et al., 2006) must be considered. In this context, faunal groups can provide effective data on ecosystem restoration (Majer, 2009; Cole et al., 2016).

In this context, insects have been considered a good alternative as bioindicators of degraded areas during the process of restoration. In addition to their representativeness and ecological importance, they are easy to sample, have a high reproductive capacity which does not cause imbalances in the community because of sampling, a short period between generations, different degrees of sensitivity, and rapid response to changes in the environment (Louzada \& Zanetti, 2013). However, the disadvantage is that many tropical species are still unknown, leading to the unavailability of identification keys (Grimbacher et al., 2007) and the need for speciesidentification specialists. Nonetheless, this disadvantage can be overcome by using higher or less specific taxonomic identification levels, in addition to the classification by functional groups, which are useful in differentiating areas (Nakamura et al., 2007).

Thus, the objective of this study was to test the assumption that some litter arthropods may be efficient bioindicators for monitoring restoration techniques in pasture-degraded areas, having potential for application in restoration monitoring programs. The following hypotheses were tested: (1) the composition of the litter insect and springtail community changes because of environmental heterogeneity resulting from different restoration techniques; (2) families of the class Insecta and species of Formicidae and Collembola from the litter respond differently to environmental heterogeneity; and (3) identification at the family level allows the comparison of areas with environmental heterogeneity.

\section{MATERIALS AND METHODS}

\subsection{Study sites}

The study was conducted in areas of Serra do Itajaí National Park (SINP) $\left(27^{\circ} 00^{\prime}\right.$ and $27^{\circ} 17^{\prime} \mathrm{S}, 49^{\circ} 01^{\prime}$ and $\left.49^{\circ} 21^{\prime} \mathrm{W}\right)$, Santa Catarina State, South Brazil. The study area is located in a 300 ha degraded area known as the Faxinal do Bepe, inside the park, in the municipality of Indaial. The occupation of Faxinal do Bepe began in 1953, which was a year marked by the exploitation of the native species for wood and nontimber purposes, such as the establishment of agricultural plantations, silviculture activities, and pastures. The altitude ranges from 600 to $800 \mathrm{~m}$, with an average annual temperature of $20^{\circ} \mathrm{C}$, a relative humidity of approximately $84 \%$, and average rainfall between 1,500 and $1,600 \mathrm{~mm}$, with well-distributed rainfall throughout the year (Wrege et al., 2009). According to the Köppen classification, the predominant climate in the region is humid mesothermic subtropical with a hot summer (Cfa) (Alvares et al., 2013). The vegetation of the region is classified as Ombrophilous Dense Montana Forest, Atlantic Forest Biome (IBGE, 2012).

Sampling areas consist of native forest, natural regeneration, and three pasture areas. Since 2014 the pasture areas have been in the process of restoration using different nucleation techniques. Thus, five treatments were determined:

- Native forest (FOR): reference area, at an advanced stage of regeneration, with a substantial wealth of arboreal and herbaceous species with a continuous sampling area with size of 12 ha $\left(27^{\circ} 6^{\prime} 19.80^{\prime \prime} \mathrm{S}, 49^{\circ} 11^{\prime} 36,00^{\prime \prime} \mathrm{W}\right.$; average altitude, $765 \mathrm{~m}$ ). The native forests surrounds the degraded area of 300 ha - Faxinal do Bepe.

- Natural regeneration (REG): areas at the edge of native forest, noncontinuous, with vegetation at an intermediate stage of succession, where a typical Ombrophilous Dense Montana Forest regeneration with arboreal and shrub species have been recorded (Adenesky-Filho et al., 2017; Maçaneiro et al., 2017) with a total area for sampling of $12 \mathrm{ha}\left(27^{\circ} 6^{\prime} 30.60^{\prime \prime} \mathrm{S}, 49^{\circ} 11^{\prime} 46.71^{\prime \prime} \mathrm{W}\right.$; average altitude, 692m).

- Seedlings planting (PLA): Pasture areas with the nucleation technique of seedling planting in modules installed. Selection of species for seedling planting was based on the floristic-forest inventory conducted in the SINP areas (Vitorino \& Adenesky-Filho, 2018; Schorn \& Maçaneiro, 2018) with a noncontinuous areas with a total area for sampling of 12 ha $\left(27^{\circ} 6^{\prime} 45.00^{\prime \prime}\right.$, $49^{\circ} 12^{\prime} 12.60$ 'W; average altitude, $\left.639 \mathrm{~m}\right)$.

- Artificial perches (PER): pasture areas with the nucleation technique of artificial perches installed. The presence of representative coverage of Pteridium aquilinum (L) Kuhn (Dennstaedtiaceae) was observed in the herbaceous stratum in this areas (Schorn \& Maçaneiro, 2018), noncontinuous areas with a total area for sampling of 12 ha $\left(27^{\circ} 6^{\prime} 35.40^{\prime \prime} \mathrm{S}, 49^{\circ} 12^{\prime} 4.20^{\prime \prime} \mathrm{W}\right.$; average altitude, $\left.661 \mathrm{~m}\right)$.

- Leaf litter transposition (LIT): pasture area with the nucleation technique of LIT installed, noncontinuous areas with a total area for sampling of $12 \mathrm{ha}\left(27^{\circ} 6^{\prime} 58.20^{\prime \prime} \mathrm{S}\right.$, $49^{\circ} 12^{\prime} 34.80^{\prime \prime} \mathrm{W}$; average altitude, $637 \mathrm{~m}$ ).

A more detailed description of the areas and nucleation techniques used is in Appendix A.

\subsection{Insecta and Collembola sampling}

Sampling was conducted from April/2017 to October/2018, bimonthly, totaling 10 collections. In each treatment, we 
established eight sampling points (replicates), $20 \mathrm{~m}$ distant from each other, randomized every 2 months inside the treatment areas. The samples were collected by the installation of pitfall traps (height: $18.5 \mathrm{~cm}$; upper diameter: $21.5 \mathrm{~cm}$; bottom diameter: $17 \mathrm{~cm}$ ) containing water, alcohol (70\%), and biodegradable detergent, which remained in the field for a period of three nights. All material contained in the traps was screened, counted, and identified. Identification was performed at the order and family levels by using the dichotomous keys in Triplehorn \& Johnson (2011) and Rafael et al. (2012). Formicidae species were identified by Guilherme Alan Klunk from Forest Monitoring and Protection Laboratory (LAMPF) of the Regional University of Blumenau (FURB) using Baccaro et al. (2005), and confirmed by Alexandre Casadei Ferreira, Thiago Sanches Ranzani da Silva and Dr. Rodrigo dos Santos Machado Feitosa from Federal University of Paraná - Universidade Federal do Paraná (UFPR). The springtails were screened, counted, morpho-specified, counted, and diaphanized in Nesbitt liquid and fixed in semi-permanent slides in Hoyer's liquid (Palacios Vargas et al., 2013). The identification was performed using the dichotomous keys available in Bretfeld (1999), Zeppelini (2012), and Bellinger et al. (1996-2019) and species were identified or confirmed by Dr. Douglas Zeppelini Filho from Paraíba State University -Universidade Estadual da Paraíba (UEPB). Specimens were incorporated into the entomological collection of the Forest Monitoring and Protection Laboratory (LAMPF) of the Regional University of Blumenau (FURB).

\subsection{Statistical analysis}

Families in the class Insecta were classified according to Friebe (1983) in dominance categories divided into eudominant, dominant, subdominant, recessive, and rare (Appendix A). The total richness of Formicidae species, total abundance of Insecta and Collembola, and Insecta families classified as dominant, eudominant, and subdominant were subjected to the Shapiro-Wilk normality test and, later, to the KruskalWallis test $(\mathrm{p}<0.05)$ and Mann-Whitney post-hoc test for nonparametric data and an analysis of variance (ANOVA) and Tukey test $(\mathrm{p}<0.05)$ for parametric data.

To evaluate litter insect fauna in the different treatments, Wardle's index V (1995) was applied to families classified as eudominant, dominant, subdominant, and recessive. The index creates a relationship between abundance in the unmanaged area (FOR) and the anthropized areas (REG, PER, LIT, PLA) (Appendix A). The index was applied to two datasets (year 1: April/2017 to December/2017 and year 2: February/2018 to October/2018) to determine whether there were changes in the inhibition categories of each family in the different areas from one year to the next.

For the Formicidae and Collembola species, the individual indicator value (IndVal) was determined to identify indicator species or groups (Dufrêne \& Legendre, 1997). The significance value for each species was determined by the Monte Carlo test, with 4,999 permutations.

To test for differences in the composition of the arthropod community, ordinances were generated from non-metric multidimensional scaling (NMDS) (Borcard et al., 2011) based on the Bray-Curtis dissimilarity. Ordinances were generated for the Insecta families, Formicidae species, and Collembola species data groups, considering one year of sampling (August/2017 to June/2018). In the Insecta family data matrix, the abundance data for the Formicidae family were excluded because of the social habits of this group. To test the significance of differences in group composition, for each map generated by NMDS, the permutation multivariate analysis of variance (PERMANOVA) analysis was performed at the 5\% significance level (Anderson, 2001). The analyses were performed using R (R Development Core Team 2009) and PAST version 3.22 (Hammer et al., 2001).

\section{RESULTS AND DISCUSSION}

A total of 53,147 litter arthropods were collected, with $53.38 \%$ in the class Insecta (distributed in 15 orders and 155 families) and $46.62 \%$ in the class Collembola. Insecta was statistically more abundant in native forest, natural regeneration, and LIT areas $(\mathrm{K}=11.66 ; \mathrm{p}=0.020)$ (Figure 1-A). No significant differences were observed in Collembola abundance among the sample areas $(\mathrm{K}=4.73 ; \mathrm{p}=0.315)$ (Figure 1-A).

Of the 155 insect families collected, two were classified as eudominant, three as dominant, six as subdominant, five as recessive, and 138 as rare (Table S2; Appendix C). Families Ptiliidae, Staphylinidae, Leiodidae, and Phoridae were statistically more abundant in native forest and natural regeneration areas. Cicadellidae and Delphacidae showed an inverse pattern, being more abundant in pasture areas (Table 1). 

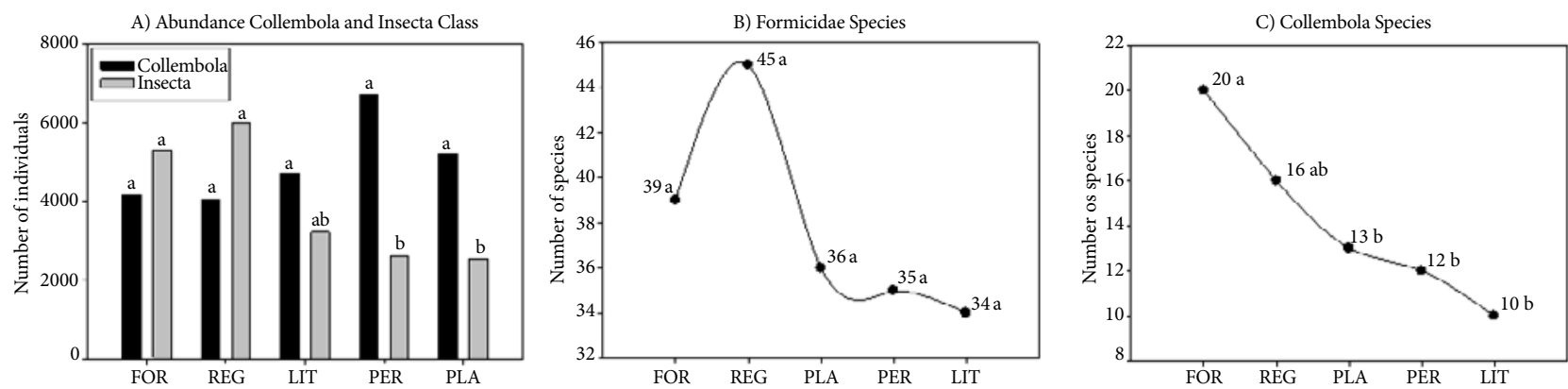

Figure 1. A) Total number of individuals of class Collembola and Insecta; B) Formicidae species richness in sample areas; C) Collembola species richness in sample areas. FOR - native forest; REG - natural regeneration; PLA - seedlings planting; PER - artificial perches; LIT - leaf litter transposition.

Table 1. Abundance of Insecta families classified as eudominant, dominant, and subdominant in the sample areas.

\begin{tabular}{|c|c|c|c|c|c|c|}
\hline Family & FOR & REG & LIT & PLA & PER & $p$ \\
\hline \multicolumn{7}{|c|}{ Coleoptera } \\
\hline Staphylinidae & $988 \mathrm{a}$ & 1797 a & $272 \mathrm{~b}$ & $177 \mathrm{~b}$ & $211 \mathrm{~b}$ & 0.0002 \\
\hline Ptiliidae ${ }^{*}$ & $915 \mathrm{a}$ & $1179 \mathrm{a}$ & $34 \mathrm{~b}$ & $41 \mathrm{~b}$ & $68 \mathrm{~b}$ & $<0.0001$ \\
\hline Leiodidae $^{*}$ & $171 \mathrm{a}$ & $139 a$ & $13 \mathrm{~b}$ & $14 \mathrm{~b}$ & $15 \mathrm{~b}$ & $<0.0001$ \\
\hline Nitidulidae & 117 & 52 & 66 & 49 & 52 & 0.1281 \\
\hline \multicolumn{7}{|c|}{ Hymenoptera } \\
\hline Chalcidoidea & 294 & 257 & 244 & 228 & 189 & 0.8222 \\
\hline \multicolumn{7}{|c|}{ Hemiptera } \\
\hline Cicadellidae $^{\star}$ & $60 \mathrm{a}$ & $87 \mathrm{a}$ & $477 \mathrm{bc}$ & $336 \mathrm{~b}$ & $237 c$ & $<0.0001$ \\
\hline Delphacidae & $15 \mathrm{a}$ & $24 \mathrm{a}$ & $138 \mathrm{ab}$ & $79 \mathrm{~b}$ & $115 \mathrm{~b}$ & 0.0028 \\
\hline \multicolumn{7}{|c|}{ Orthoptera } \\
\hline Gryllidae & 402 & 143 & 141 & 127 & 125 & 0.4625 \\
\hline \multicolumn{7}{|c|}{ Diptera } \\
\hline Sciaridae & 68 & 336 & 219 & 91 & 20 & 0.0734 \\
\hline Phoridae $^{*}$ & $268 \mathrm{a}$ & $244 \mathrm{ab}$ & $49 \mathrm{c}$ & $70 \mathrm{bc}$ & $86 \mathrm{bc}$ & 0.0051 \\
\hline Sphaeroceridae & 16 & 3 & 139 & 111 & 132 & 0.0628 \\
\hline
\end{tabular}

*Values followed by the same letter are not statistically different according to the Kruskal-Wallis and Mann-Whitney post-hoc test $(\mathrm{p}<0.05)$. FOR - native forest; REG - natural regeneration; PLA - seedlings planting; PER - artificial perches; LIT - leaf litter transposition.

From the families collected, 16 were analyzed using Wardle's V index (Table S1, Appendix B). In the first sampling year, all treatment sample areas, except natural regeneration, showed more than $50 \%$ of the families in the categories of extreme and moderate inhibition. For natural regeneration, the highest percentage ( $60 \%)$ was observed in the category of slight inhibition (Figure 2-A). In the second sampling year, in areas of natural regeneration treatment, approximately $60 \%$ of families were recorded in the categories of stimulation and no change (Figure 2-B). The Aphididae and Sphaeroceridae families were extremely stimulated in all treatment areas, except natural regeneration. Ptiliidae, Staphylinidae, and Tipulidae were inhibited in all treatment areas, except the area of natural regeneration (Table S1, Appendix B).

For Formicidae, 2,253 individuals were collected from seven subfamilies, 24 genera, and 95 species (Table S4, Appendix D). We observed the highest species richness in the natural regeneration area, followed by the native forest. Species richness did not differ statistically among sampled areas $(\mathrm{F}=0.42 ; p=0.79)$ (Figure $1-\mathrm{B})$.

Over the total sampling period, 13,294 springtails were collected. From August/2017 to June/2018, 3,841 individuals were collected and subsequently distributed into three orders, nine families, 19 genera, and 20 species (Table S3, Appendix D). Species richness differed significantly among treatment areas $(F=9.09, p=0.0001)$, being higher in the native forest area, followed by natural regeneration (Figure 1-C).

For Formicidae, IndVal presented 12 indicator species, with the largest number of species observed in the native forest area and five species indicating areas in the initial restoration process (Table 2). For Collembola, 11 indicator species were observed, with the largest number observed in the native forest area $(n=8)$. Only two species were indicative of areas with nucleation techniques (Table 2). 
A) Year 1

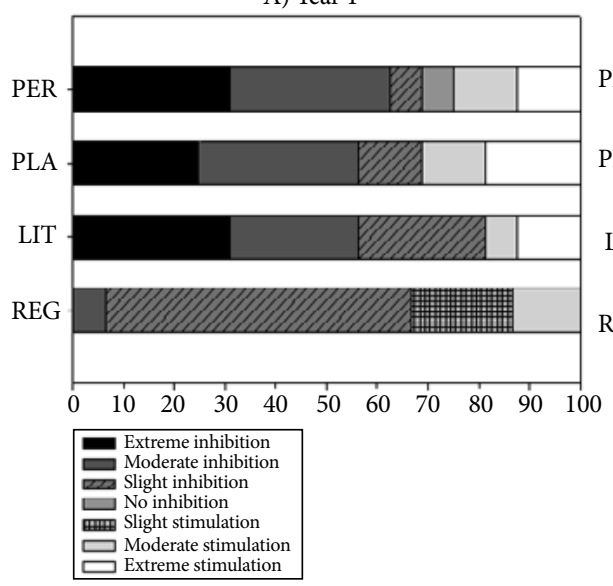

B) Year 2

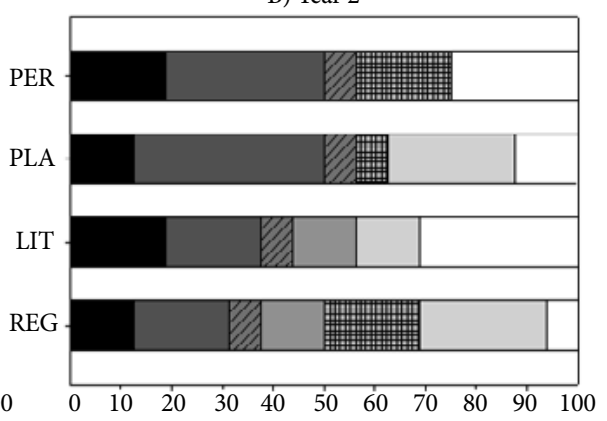

Figure 2. Results (\%) of the application of Wardle V index (Wardle, 1995) in the data for families of the class Insecta in sampled areas in the first (A) and second (B) sampling years. REG - natural regeneration; PLA - seedlings planting; PER - artificial perches; LIT - leaf litter transposition.

Table 2. Formicidae and Collembola species indicators in the areas from Faxinal do Bepe, PNSI, SC.

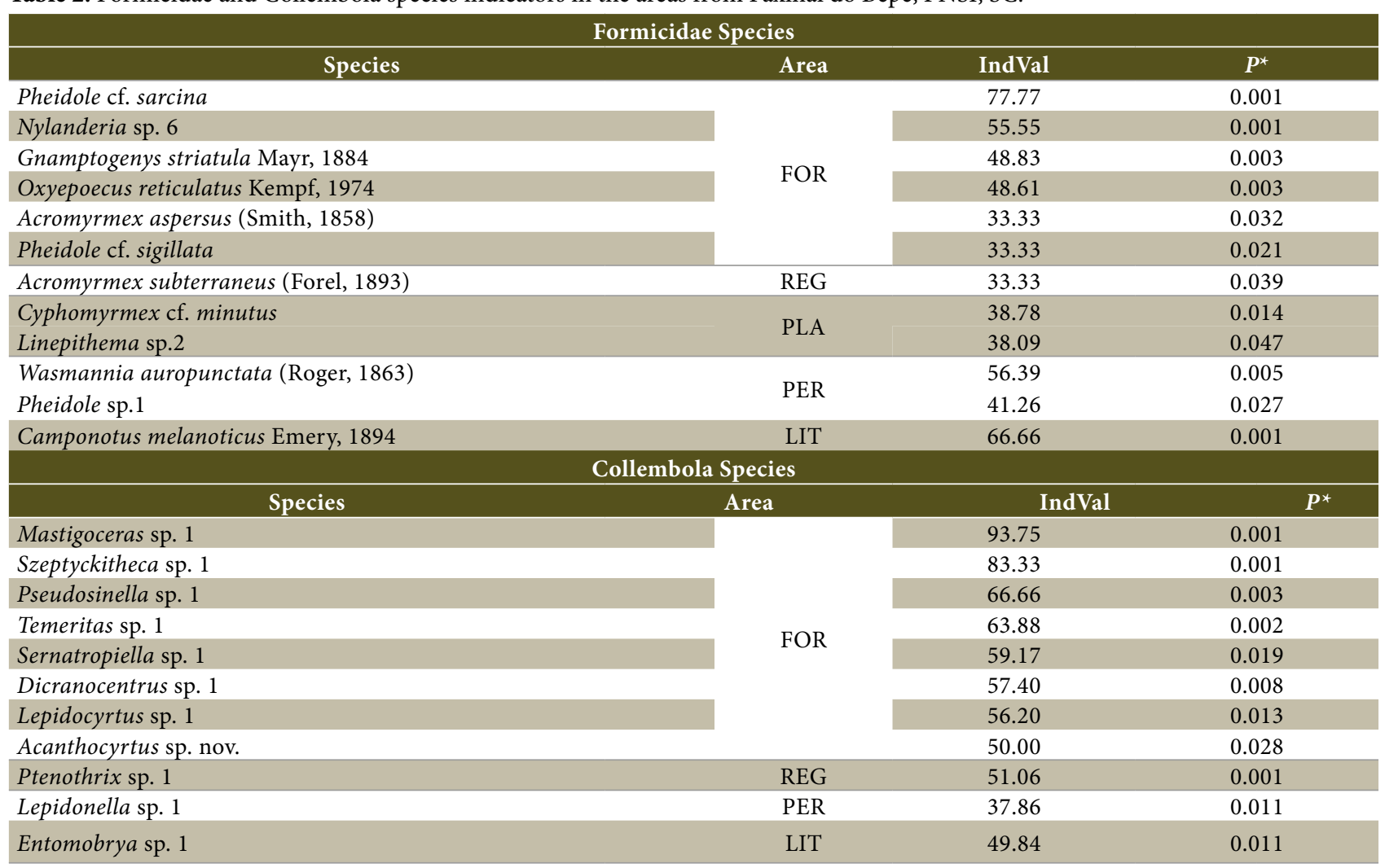

${ }^{*}$ Probability resulting from the permutation test.

The composition of the Insecta families and the NMDS and PERMANOVA evaluations exhibited significant differences among the treatment areas ( $p=0.0001$ ), Formicidae species (stress $=0.19 ; \mathrm{F}=2.89 ; \mathrm{p}=$ 0.0001 ), and Collembola species (stress $=0.19 ; \mathrm{F}=2.73 ; \mathrm{p}=$ 0.0004) (Figure 3; Table 3). All identification levels analyzed (family and species) allowed discrimination between the treatments or the vegetation stage of succession. The native forest area was statistically different from all other sampled areas for all groups analyzed, except for Insecta families and Collembola species, where it was statistically similar to natural regeneration areas (Table 3 ). 

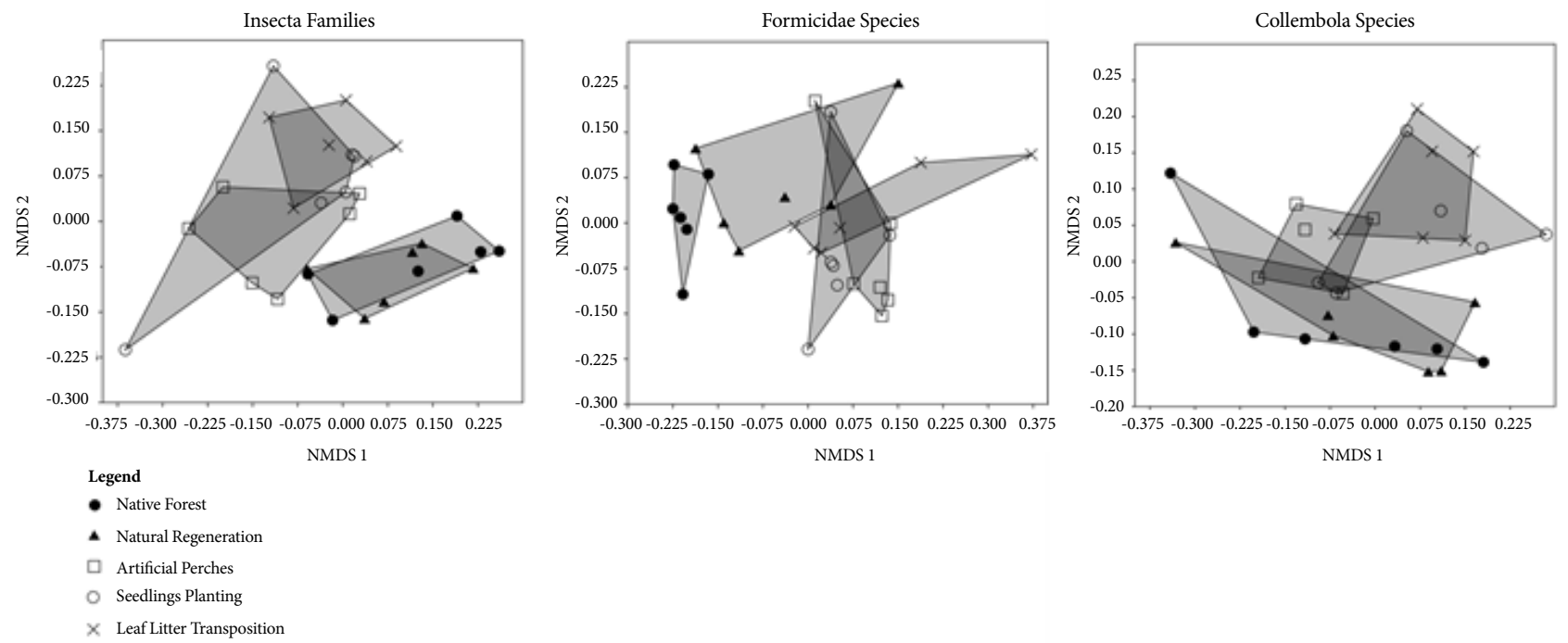

Figure 3. Ranking by NMDS (Non-Metric Multidimensional Scaling) of sampled areas in the Faxinal do Bepe, PNSI, SC.

Table 3. PERMANOVA results based on the Bray-Curtis similarity matrix for the matrices of the Insecta families, Formicidae species, and Collembola species. P values followed by ${ }^{*}$ indicate significant differences at $\mathrm{p}<0.05$. REG - natural regeneration; PLA - seedlings planting; PER - artificial perches; LIT - leaf litter transposition.

\begin{tabular}{|c|c|c|c|c|}
\hline \multicolumn{5}{|c|}{ Insecta Families - PERMANOVA (F: 4,$25 ; p: 0,0001$ ) } \\
\hline & PLA & PER & REG & LIT \\
\hline FOR & $0.0030^{*}$ & $0.0045^{*}$ & 0.2302 & $0.0054^{*}$ \\
\hline PLA & - & 0.2087 & $0.0030^{*}$ & 0.2988 \\
\hline PER & & - & $0.0046^{*}$ & 0.2630 \\
\hline REG & & & - & $0.0054^{*}$ \\
\hline \multicolumn{5}{|c|}{ Formicidae Species - PERMANOVA $(\mathrm{F}=2.89 ; p=0.0001)$} \\
\hline & PLA & PER & REG & LIT \\
\hline FOR & $0.0024^{*}$ & $0.0024^{*}$ & $0.0066^{*}$ & $0.0015^{*}$ \\
\hline PLA & - & 0.104 & $0.0176^{*}$ & 0.125 \\
\hline PER & & - & $0.0096^{*}$ & 0.0528 \\
\hline REG & & & - & 0.0791 \\
\hline \multicolumn{5}{|c|}{ Collembola Species - PERMANOVA $(\mathrm{F}=2.73 ; p=0.0004)$} \\
\hline & PLA & PER & REG & LIT \\
\hline FOR & 0.0888 & $0.0061^{*}$ & 0.6243 & $0.0014^{*}$ \\
\hline PLA & - & $0.0366^{*}$ & 0.1185 & 0.4946 \\
\hline PER & & - & $0.0085^{*}$ & $0.0041^{*}$ \\
\hline REG & & & - & $0.0049^{*}$ \\
\hline
\end{tabular}

\subsection{Class Insecta families}

From the analysis of the composition of Insecta families, it was possible to observe the differences in the composition of the litter insect fauna between the areas with developed tree coverage (native forest and natural regeneration) and pasture areas in the initial succession process. We believe that these differences are related to aspects of vegetation cover that directly and indirectly influence litter, such as species diversity and canopy shading.

Through statistical analysis of the abundance of families in the sampled areas, it was observed that the families Ptiliidae,
Staphylinidae, Leiodidae, and Phoridae were representative of the areas with an advanced stage of succession, indicating the preference of these organisms for well-rounded, structured, litter-shaded, and shaded areas. Family Ptiliidae is composed of fungivorous beetles (Darby \& Chaboo, 2015); therefore, they inhabit places where decaying organic matter and stable microclimatic conditions are present, which explains why this family is extremely inhibited in pasture sampling areas. Areas with tree vegetation supported higher moisture in the litter and lower light, favoring the proliferation of fungi, which is the food resource of these organisms (Marinoni \& Ganho, 2003). In this context, because of their food specialization 
and the demands of environmental conditions, ptilids are good bioindicators of the restoration of degraded areas of the Atlantic Rain Forest. Other favorable characteristics for the use of this family as bioindicators are the ease of identification in which they differ from the other beetles by the presence of bristle fringes on their membranous wing margins (Casari \& Ide, 2012) that are easy to observe under a stereoscopic microscope or magnifying glass as well as because they were classified as eudominant, being a representative family of litter insect fauna. Frequently, this family is a representative of insect fauna surveys at the soil-litter interface (Marinoni \& Ganho, 2003; Brito-Silva et al., 2016).

The Leiodidae family is mainly formed by detritivorous insects (Casari \& Ide, 2012). Some species are fungivorous and their eating habits have revealed that litter deposition and the presence of woody material provide food resources for these organisms (Chandler \& Peck,,1992). The Staphylinidae family is often the most abundant in Coleoptera surveys (Hopp et al., 2003; Marinoni \& Ganho, 2010), forming an extremely varied group that exploits a wide range of food resources and includes predators and detritivores. Our data show the preference of these organisms for environments in more advanced stages of ecological succession, where there is greater availability of resources, such as litter formation for detritivores and the presence of invertebrates for predators. Our results corroborate those observed by Hopp et al. (2010), who analyzed the chronosequence of forest regeneration in the Atlantic Forest, phytophysiognomy Ombrophilous Dense Submontane Forest.

Families Cicadellidae and Delphacidae (Hemiptera) were representative of pasture areas under restoration, indicating that these organisms have high tolerance to environmental changes as these families were stimulated. Beiroz et al., (2014) observed the order Hemiptera as an indicator of pasture.

Wardle inhibition categories revealed the same pattern observed from household abundance analysis, where families, such as Ptiliidae, Staphylinidae, Leiodidae, and Phoridae were inhibited in areas undergoing initial restoration and some were stimulated in areas with nucleation techniques. These families occupy higher trophic levels, such as predation and fungivory, and indicate the effects of degradation on ecological interactions and also that the succession process is in its early stages. In general, it was observed that in areas under restoration, families associated with pastures were stimulated, whereas families associated with forest environments were inhibited.

The extreme stimulation of the families Aphididae, Delphacidae, and Sphaeroceridae in these areas indicates the high tolerance and adaptation of these families to the anthropization of the environment, either because of the availability of food resources, reduced competition, and/or tolerance to microclimate changes. Species found in pasture areas tend to be generalists and/or are characteristic of open environments (Beiroz et al., 2014).

In the area of artificial perches, the highest occurrence of extremely inhibited families was observed, which may be related to the presence of the species Pteridium aquilinum (Schorn \& Maçaneiro, 2018). This species is highly competitive, with a high adaptive capacity and resistance to unfavorable climates and insect and pathogen attacks (Hojo-Souza et al., 2010). They may compromise natural regeneration (Ribeiro et al., 2013; Brandão et al., 2016) and were characterized in a model of ecological succession by inhibition (Connel \& Slatyer, 1977). This inhibition of regeneration may affect the processes of litter arthropod recolonization, causing a delay in the restoration process.

\subsection{Formicidae species}

Species richness in the native forest area was lower than that of the natural regeneration area and did not differ statistically from pasture areas under the restoration process. A possible explanation for this lack of significance is the presence of forest fragments near the study areas, which may act as sources of recolonization for ants (Schmidt et al., 2013). However, from NMDS and the PERMANOVA, the species composition of the native forest area was statistically different from that of the other sampled areas, allowing the observation of the gradient of ecological succession of these areas. Other studies have also reported this difference in the composition of ant assemblages between forest, grassland, and different levels of ecological succession (see Nakamura et al., 2007; Silva et al., 2007; Schmidt et al., 2013). According to Schmidt et al., (2013), the difference between ant species when comparing pasture areas and forest remnants at different times of secondary succession is reinforced by the age of the remnant. According to the same authors, this difference can be explained by the development of vegetation cover, which negatively affects open and warm areas and increases shaded and cold environments.

Pheidole cf. sarcina was an indicator of the native forest area. They have varied eating habits, ranging from generalist to omnivorous predators (Brandão et al., 2012). Its high indication value observed in the native forest area shows specificity and fidelity to forest environments, which may be related to the litter component and vegetation cover of the area. With successional advancement, canopy closure and shading increase, resulting in decreased leaf deposition and 
increased litter deposition (Bianchin et al., 2016), favoring the establishment of $P$. sarcina, Forel, 1912 because this species presents the behavior of colonizing branches present in the litter (Fernandes et al., 2018).

The species Wasmannia auropunctata and Camponotus melanoticus were indicative of areas with artificial perches and LIT; that is, they indicated areas in the initial process of ecological restoration, with characteristics of open environments. W. auropunctata have an omnivorous habit in its natural ecosystem, this species is competitive and dominant in disturbed environments (Orivel et al., 2009; Rosumek, 2017). For C. melanoticus, there is little information regarding its biology and ecology. Neves et al., (2013) classified this species as a dominant tree species, because they nest in trees and show very active and aggressive behavior. Our results suggest a preference of this species for open and disturbed environments, corroborating Schmidt et al., (2013) in that this species occurs preferentially in pasture areas in the seasonal forest regions of the Atlantic Forest.

\subsection{Collembola species}

The number of trees, crown diameter, and litter depth are parameters of the plant community that are positively correlated with the richness of springtail species (Zeppelini et al., 2009), which explains the higher species richness in the most advanced successional stage areas. These factors also explain the differences in species composition observed by NMDS and PERMANOVA, with a marked difference between the sample areas where the tree component was absent or present. Our data corroborate those of Baretta et al. (2008) and Zeppelini et al. (2009).

The greater number of native forest indicator species is indicative of the preference of the springtails for forest environments in the advanced conservation stage. The low indication values in the areas of natural regeneration and restoration processes indicated that few species were able to tolerate environmental changes resulting from vegetation suppression, which highlights the sensitivity of the springtails to its changes and bioindicator capacity.

Surveys to analyze Collembola's biology and indicating their capacity in the Atlantic Forest are scarce, especially in southern Brazil. Some experiments have used eco-morphological features rather than taxonomic identification in ecological restoration scenarios or environments with different land uses (e.g., Oliveira Filho et al., 2016; Winck et al., 2017). Thus, the ecology information and responses of different species in restoration scenarios are incipient. The highest indicator values of Mastigoceras sp. 1 and Szeptyckitheca sp.
1 for native forest areas indicated that these species have a preference for conserved environments. Zeppelini et al. (2019) reported the presence of Szeptyckitheca on litter in preserved areas of the Atlantic Forest in the municipality of Jundiaí, State of São Paulo.

\subsection{Taxonomy identification level}

All taxonomic identification levels discriminated pasture sampling areas from regeneration and native forest areas. Observing differences in the arthropod community is useful for observing environmental changes and use as bioindicators, which was confirmed in our survey and corroborated that of other surveys (see Nakamura et al., 2007). Changes in species composition during the advancement of ecological succession were observed by Hopp et al. (2010) in the beetle community (Insecta: Coleoptera).

Many factors determine the robustness of the invertebrate community in detecting changes that occur in ecosystems, including sample sufficiency, types of data analysis, the level of taxonomicidentification, and the difference between environmental gradients (Grimbacher et al., 2007). The same authors, when analyzing the community of beetles (Coleoptera) collected with interception flight traps in Australia, observed that less specific identification levels (families) exhibited better performance than when using species and univariate tests comparing areas of rainforest and pasture. Nakamura et al. (2007) concluded that the use of deeper taxonomic levels (e.g., Formicidae genera or species) does not necessarily increase robustness levels when considering less specific identification levels (e.g., order Arthropoda). Similar conclusions were observed in our results, where all levels of taxonomic identification allowed us to observe differences between sample areas.

\section{CONCLUSIONS}

Composition of Insecta families and species in Formicidae and Collembola followed the successional pattern of the sampled areas and was an effective metric for restoration monitoring. Species richness of the springtail community was a bioindicator parameter.

Families Staphylinidae, Leiodidae, and Phoridae, and species Pheidole sarcina, Mastigoceras sp. 1, and Szeptyckitheca sp. 1 were bioindicators of conserved areas. Families Cicadellidae and Delphacidae, and species Camponotus melanoticus and Wasmannia auropunctata were bioindicators of disturbed areas in early stages of restoration.

Less specific identification levels from the class Insecta (family) may be used as bioindicators. 


\section{SUBMISSION STATUS}

Received: 17 Feb. 2021

Accepted: 16 Aug. 2021

Associate editor: João Vicente de Figueiredo Latorraca

\section{CORRESPONDENCE TO Marcelo Diniz Vitorino}

São Paulo, 3250, CEP 89030-000, Blumenau, SC, Brasil

e-mail: dinizvitorino@gmail.com

\section{AUTHORS' CONTRIBUTIONS}

Taise Cristina Plattau Arenhardt: Data curation (Equal); Formal analysis (Equal); Methodology (Equal); Validation (Equal); Writingoriginal draft (Equal); Writing-review \& editing (Equal).

Marcelo Diniz Vitorino:Conceptualization (Equal); Data curation (Equal); Formal analysis (Equal); Funding acquisition (Equal); Investigation (Equal); Methodology (Equal); Project administration (Equal); Supervision (Equal); Writing-original draft (Equal); Writing-review \& editing (Equal).

Sebastião Venâncio Martins: Data curation (Supporting); Investigation (Supporting); Methodology (Supporting); Supervision (Equal) Validation (Supporting); Writing-original draft (Equal).

\section{SUPPLEMENTARY MATERIAL}

The following online material is available for this article:

APPENDIX A

APPENDIX B

APPENDIX C

APPENDIX D

\section{REFERENCES}

Adenesky-Filho E, Maçaneiro JP, Vitorino MD. How to select potential species for ecological restoration of rain forest - Southern Brazil. Applied Ecology and Environmental Research 2017; 15(3):1671-2684.

Alvares CA, Stape JL, Sentelhas PC, Gonçalves JLM, Sparovek G. Koppen's climate classification map for Brazil. Meteorologische Zeitschrift 2013; 22(6):711-728.

Anderson MJ. A new method for non-parametric multivariate analysis of variance. Austral Ecology 26(1):32-46; 2001.

Baccaro FB, Feitosa RM, Fernandez F, Fernandes IO, Izzo TJ, Souza JLP, Solar R. Guia para os gêneros de formigas do Brasil. INPA, Manaus, Amazonas; 2015.

Baretta D, Ferreira CS, Sousa JP, Cardoso EJBN. Colêmbolos (Hexapoda: Collembola) como bioindicadores de qualidade do solo em áreas com Araucaria angustifolia. Revista Brasileira de Ciência do Solo 2008; 32:2693-2699.

Beiroz W, Audino LD, Queiroz ACM, Rabello AM, Boratto IA, Silva Z, Ribas CR. Structure and composition of edaphic arthropod community and its use as bioindicators of environmental disturbance. Applied Ecology and Environmental Research 2014; 12(2):481-491.

Bellinger PF, Christiansen KA, Janssens F. Checklist of the Collembola http://www.collembola.org; 2019.

Bianchin JE, Marques R, Britez RM, Capretz RL. Deposição de fitomassa em formações secundárias na Floresta Atlântica do Paraná. Floresta e Ambiente 2016; 23(4):524-533.

Borcard D, Gillet F, Legendre P. Numerical ecology with R. Springer; 2011.

Bourg A, Escobar F, Macgregor-Fors I, Moreno CE. Got dung? resource selection by dung beetles in Neotropical forest fragments and cattle pastures. Neotropical Entomology 2016; 45(5):490-498.

Brancalion PHS, Viani RAG, Rodrigues RR, Gandolfi S. Avaliação e monitoramento em áreas em processo de restauração. Pages 262291 In: Martins SV (ed) Restauração ecológica de ecossistemas degradados. UFV, Viçosa, Minas Gerais; 2012.

Brandão CRF, Silva RR, Delabie JHC. Neotropical ants (Hymenotpera) functional groups: nutritional and applied implications. Pages 213236 In: Panizzi AR, Parra JRP (eds). Insect bioecology and nutrition for integrated pest management. CRC Press, Boca Raton; 2012.

Brandão JFC, Martins VS, Brandão IJ. Potencial de regeneração de uma área invadida por Pteridium aquilinum no Parque Nacional do Caparaó. Revista Árvore 2016; 46(4):543-552.

Brasil (2000) Lei $n^{\circ} 9.985$, de 18 de julho de 2000. Sistema Nacional de Unidades de Conservação da Natureza, Brasília, Distrito Federal.

Bretfeld G. Synopses on Palaearctic Collembola: Symphypleona. Staatliches Museum für Naturkunde Görlitz; 1999.

Brito-Silva BC, Pina WC, Silva A. O efeito de borda na dinâmica de besouros em fragmento de Mata Atlântica de Tabuleiro. Ecologia e Nutrição Florestal 2016; 4(3):78-86.

Casari AS, Ide S. Coleoptera. In: Rafael JÁ, Melo GAR, Carvalho CJB, Casari AS, Constantino R (eds) Insetos do Brasil: Diversidade e taxonomia. Holos, Ribeirão Preto, São Paulo; 2012.

Cassagne N, Gers C, Gauquelin T. Relationships between Collembola, soil chemistry and humus types in forest stands (France). Biology and Fertility of Soils 2003; 37(6):655-361.

Chandler DS, Peck SB. Diversity and Seasonality of Leiodid Beetles (Coleoptera: Leiodidae) in an Old-Growth and a 40-Year-Old Forest in New Hampshire. Environmental Entomology 1992; 21(6):1283-1293.

Cole RJ, Holl KD, Zahawi RA, Wickey P, Townsend AR. Leaf litter arthropod responses to tropical forest restoration. Ecology and Evolution 2016; 6(15):5158-5168.

Connel JH, Slatyer RO. Mechanisms of succession in natural communities and their role in community stability and organization. American Naturalist 1977; 111(982):1119-1144.

Dangles O, Casas J. Ecosystem services provided by insects for achieving sustainable development goals. Ecosystem Services 2019; 35:109-115.

Darby M, Chaboo CS. Beetles (Coleoptera) of Peru: a survey of the families, Ptiliidae Heer, 1843. Journal of the Kansas Entomological Society $2015 ; 88(2): 182-183$.

Dufrêne M, Legendre P. Species assemblages and indicator species: the need for a flexible asymmetrical approach. Ecological Monographs 1997; 67(3):345-366. 
Fernandes TT, Souza-Campana DR, Silva RR, Morini MSC. Ants that frequently colonize twings in the leaf litter of different vegetation habitats. Sociobiology 2018; 65(2):340-344.

Friebe B. Zur Biologie eines Buchenwaldbodens: 3. Die kaferfauna $1983 ; 41: 45-80$.

Gatica-Saavedra P, Echeverría C, Nelson C. Ecological indicators for assessing ecological success of forest restoration: a world review. Restoration Ecology 2017; 25(6):850-857.

Grimbacher PS, Catterall CP, Kitching RL. Detecting the effects of environmental change above the species level with beetles in a fragmented tropical rainforest landscape. Ecological Entomology 2007; 33(1):66-79.

Hammer $\varnothing$, Harper AT, Ryan PD. PAST: Paleontological Statistics Software Package for Education and Data Analysis. Palaentologia Electronica 4(1):4-9; 2001.

Herrick JE, Schuman GE, Rango A. Monitoring ecological processes for restoration projects. Journal of Nature Conservation 2006; 14:161-171.

Hojo-Souza NS, Carneiro CM, Santos RC. Pteridium aquilinum: o que sabemos e o que ainda falta saber. Bioscience Journal 2010; 26(5):798-808.

Hopp PW, Ottermanns R, Caron E, Meyer S, Ro $\beta$-Nickoll M. Recovery of litter inhabiting beetle assemblages during forest regeneration in the Atlantic forest of Southern Brazil. Insect Conservation and Diversity 2010; 3(2):103-113.

IBGE, Instituto Brasileiro de Geografia e Estatística. Manual Técnico da Vegetação Brasileira; 2012.

Joly CA, Metzger JP, Tabarelli M. Experiences from the Brazilian Atlantic Forest: ecological findings and conservation initiatives. New Phytologist 2014; 204(3):459-473.

Jones CG, Lawton JH, Shachak M. Organisms as Ecosystem Engineers. Oikos 1994; 69(3):373-386.

Lavelle P, Decaëns T, Aubert M, Barot S, Blouin M, Bureau F, Margerie P, Mora P, Rossi J-P. Soil invertebrates and ecosystem services. European Journal of Soil Biology 2006; 42(1):S3-S15.

Legendre P, Gallagher ED. Ecologically meaningfull transformations for ordination of species data. Oecologia 2001; 129(2):271-280.

Lewinsohn T, Prado PI. Quantas espécies há no Brasil? Megadiversidade 2005; 1(1):36-42.

Louzada J, Zanetti R. Bioindicadores de impactos ambientais. Pages139-168 In: Moreira FMS, Cares JE, Zanetti R, Stürmer SL (eds) O ecossistema solo: componentes, relações ecológicas e efeitos na produção vegetal. UFLA, Lavras, Minas Gerais; 2013.

Maçaneiro JP, Liebsch D, Gaspar AL, Galvão F, Schorn LA. Structural and floristic variation in an Atlantic Subtropical Rainforest in Southern Brazil. Floresta e Ambiente 2019; 26(1): 1-10.

Majer JD. Animals in the Restoration Process - Progressing the Trends. Restoration Ecology 2009; 17(3):315-319.

Marinoni RC, Ganho NG. Fauna de Coleoptera no Parque Estadual de Vila Velha, Ponta Grossa, Paraná, Brasil. Abundância e riqueza das famílias capturadas através de armadilhas de solo. Revista Brasileira de Zoologia 2003; 20(4):737-744.

Myers N, Mittermeier RA, Mittermeier CG, Fonseca GAB, Kent J. Biodiversity hotspots for conservation priorities. Nature 2000; 403(6772):853-858.
Nakamura A, Catterall CP, House APN, Kitching RL, Burwell CJ. The use of ants and other soil and litter arthropods as bio-indicators of the impacts of rainforests clearing and subsequent land use. Journal of Insect Conservation 2007; 11(2):177-186.

Neves FS, Queiroz-Dantas KS, Rocha WD, Delabie JHC. Ants of Three Adjacent Habitats of a Transition Region Between the Cerrado and Caatinga Biomes: The Effects of Heterogeneity and Variation in Canopy Cover. Neotropical Entomology 2013; 42(3):258-268.

Oliveira Filho LCI, Filho OK, Baretta D, Tanaka CAS, Sousa JP. Collembola Community Structure as a Tool to Assess Land Use Effects on Soil Quality. Revista Brasileira de Ciência do Solo 2016; 40:1-18.

Orivel J, Grangier J, Foucaud J, Breton JLE, Andrès FX, Jourdan H, Delabie JHC, Fournier D, Cerdan P, Facon B, Estoup A, Dejean A. Ecologically heterogeneous populations of the invasive ant Wasmannia auropunctata within its native and introduced ranges. Ecological Entomology 2009; 34(4):504-512.

Palacios-Vargas JG, Recamier BEM, Zeppelini D. Técnicas atuais para estudos de micro e mesoartrópodes do solo. EDUEPB, Campina Grande, João Pessoa; 2013.

Rafael JÁ, Melo GAR, Carvalho CJB, Casari AS, Constantino R Insetos do Brasil: Diversidade e taxonomia. Holos, Ribeirão Preto; 2012.

Ribeiro SC, Botelho AS, Fontes MAL, Garcia PO, Almeida HS. Regeneração natural em áreas desmatadas e dominadas por Pteridium aquilinum (L.) Kuhn. na Serra da Mantiqueira. Cerne 2013; 19(1):65-76.

Rosumek FB. Natural history of ants: What we (do not) know about trophic and temporal niches of neotropical species. Sociobiology 2017; 64(3):244-255.

Rusek J. Biodiversity of Collembola and their functional role in the ecosystem. Biodiversity and Conservation 1998; 7(9):1207-1219.

Salomão RP, Brito LC, Iannuzzi L, Lira AFA, Albuquerque CMA. Effects of environmental parameters on beetle assemblage in a fragmented tropical rainforest of South America. Journal of Insect Conservation 2019; 23(1); 111-121.

Schmidt FA, Ribas CR, Schoereder JH. How predictable is the response of ant assemblages to natural forest recovery? Implications for their use as bioindicators. Ecological Indicators 2013; 24:158-166.

Schorn LA, Maçaneiro JP. Levantamento da vegetação. Pages149-170 In: Vitorino MD, Adenesky-Filho (orgs) Diagnóstico prévio: subsídio preliminar para projetos de restauração ecossistêmica. Edifurb, Blumenau, Santa Catarina; 2018.

Schowalter TD, Noriega JA, Tscharntke T. Insects effects on ecosystem services. Basic and Applied Ecology 2018; 26:1-7.

Ser, Society for Ecological Restoration International. Princípios da SER International sobre a restauração ecológica http://www.ser.org (accessed 11 march 2019); 2004.

Silva RR, Feitosa RSM, Ebernhardt F. Reduced ant diversity along a habitat regeneration gradient in the southern Brazilian Atlantic Forest. Forest Ecology and Management 2007; 240(1-3):61-69.

Suganuma M, Durigan G. Indicators of restoration success in riparian tropical forests using multiple reference ecosystems. Restoration Ecology 2015; 23(3):238-251.

Triplehorn CA, Johnson NF. Estudo dos insetos: Tradução de Borror and Delong's introduction of the study of insects. Cengage Learning, São Paulo; 2011. 
Vibrans AC, Mcroberts RE, Lingner DV, Nicoletti AL, Moser P. Extensão original e remanescentes da Floresta Ombrófila Densa em Santa Catarina. Pages25-36 In: Vibrans AC, Sevegnani L, Gasper AL, Lingner DV (eds) Inventário Florístico Florestal de Santa Catarina, Vol. IV, Floresta Ombrófila Densa. Edifurb, Blumenau, Santa Catarina; 2013.

Vitorino MD, Adenesky-Filho E. Diagnóstico prévio: subsídio preliminar para projetos de restauração ecossistêmica. Edifurb, Blumenau, Santa Catarina; 2018.

Wardle DA. Impacts of disturbance on detritus food webs in agroecosystems of contrasting tillage and weed management practices. Advances in Ecological Research 1995; 26:105-182.

Winck BR, Sá ELS, Rigotti VT, Chuavat M. Relationship between land-use types and functional diversity of epigeic Collembola in Southern Brazil. Applied Soil Ecology 2017; 109:49-59.
Wrege MS, Steinmetz S, Júnior CR, Almeida IR. Atlas climático da Região Sul do Brasil: Estado do Paraná, Santa Catarina e Rio Grande do Sul. Embrapa Clima Temperado, Colombo: Embrapa Florestas; 2009.

Zeppelini D, Bellini BC, Creão-Duarte JA, Hernandez MII. Collembola as bioindicators of restoration in mined sand dunes of Northeastern Brazil. Biodiversity and Conservation 2009; 18(5):1161-1170.

Zeppelini D. Collembola. Pages 201-212 In: Rafael JÁ, Melo GAR, Carvalho CJB, Casari AS, Constantino R Insetos do Brasil: Diversidade e taxonomia. Holos, Ribeirão Preto; 2012.

Zeppelini D, Lopes BCH, Lima ECA. A New Species of Szeptyckitheca (Collembola, Symphypleona, Sphyrothecinae) from Brazil. Neotropical Entomology 2019; 48(2):269-276. 